\title{
Cry2A toxins from Bacillus thuringiensis expressed in insect cells are toxic to two lepidopteran insects
}

\author{
G. M. S. Lima $\cdot$ R. W. S. Aguiar $\cdot$ R. F. T. Corrêa \\ E. S. Martins - A. C. M. Gomes - T. Nagata • \\ M. T. De-Souza $\cdot$ R. G. Monnerat $\cdot$ B. M. Ribeiro
}

Received: 31 January 2008/Accepted: 1 August 2008/Published online: 12 August 2008

(C) Springer Science+Business Media B.V. 2008

\begin{abstract}
The cry $2 A a$ and $c r y 2 A b$ genes from a Brazilian Bacillus thuringiensis strain were introduced into the genome of the baculovirus Autographa californica multiple nucleopolyhedrovirus (AcMNPV) in order to evaluate the heterologous proteins expression in insect cells and their toxicity to different insects. The recombinant viruses (vAcCry2Aa and vSynCry2Ab) were amplified in Trichoplusia ni (BTI-Tn5B1-4) cells and used to infect Spodoptera frugiperda larvae. Total extracts from S. frugiperda infected with the recombinant viruses were analysed by SDS-PAGE, which detected the presence of polypeptides around $65 \mathrm{kDa}$. Cuboid-shaped protein crystals were observed in insect extracts by light and scanning electron microscopy. Bioassays, using the heterologous proteins showed toxicity against second instar A. gemmatalis larvae (Cry2Aa) with a $\mathrm{LC}_{50}$ of $1.03 \mu \mathrm{g} / \mathrm{ml}$ and second instar S. frugiperda larvae (Cry2Ab) with a $\mathrm{LC}_{50}$ of $3.45 \mu \mathrm{g} / \mathrm{ml}$. No toxic activity was detected for Aedes aegypti and Culex quinquenfaciatus.
\end{abstract}

Keywords Baculovirus - Cry2Aa - Cry2Ab . Bacillus thuringiensis · Lepidopteran insects

G. M. S. Lima - R. W. S. Aguiar - R. F. T. Corrêa ·

E. S. Martins - T. Nagata - M. T. De-Souza · B. M. Ribeiro ( $\square)$ Department of Cell Biology, University of Brasília, 70910-900

Brasilia, DF, Brazil

e-mail: bergmann@unb.br

E. S. Martins - A. C. M. Gomes - R. G. Monnerat Embrapa - Recursos Genéticos e Biotecnologia, C.P 02373, 70770-900 Brasilia, DF, Brazil

\section{Introduction}

In the past few decades, several research groups have been looking for safer environmental alternatives to decrease the use of chemicals insecticides for the control of insect pests (Estruch et al. 1997). One of these alternatives is the use of biological control agents for insect control (Schnepf et al. 1998; el-Bendary 2006). Bacillus thuringiensis, a Grampositive bacteria, is the world most widely used biological control agent and is considered to be safe due to its specificity against target insects and its innocuity to other organisms, including mammals (Pang et al. 1992; Schnepf et al. 1998).

The entomopathogenic activity of $B$. thuringiensis is due to the presence of crystalline inclusions called deltaendotoxins or Cry proteins, produced in the stationary phase of growth and accumulated in the mother-cell compartment during sporulation. These proteins might represent up to $25 \%$ dry weight of the sporulated cells (Lereclus et al. 1989).

Crystal proteins, when ingested by susceptible larvae, are solubilized by the alkaline $\mathrm{pH}$ in the larval midgut and released as protoxins that will be activated by serine-proteases to recognize and bind to midgut receptors. After that, the toxins are inserted into the midgut cells membranes forming pores provoking destabilization of the cell osmotic gradient leading to cell lysis and later on, the death of the insect (Schnepf et al. 1998; de Maagd et al. 2001; Bravo et al. 2007).

Classification of Cry proteins is based on the identity of amino acids (Crickmore et al. 1998) and so far, more than 350 cry genes have been sequenced and the proteins classified in 53 groups (http://www.lifesci.sussex.ac.uk/home/ Neil_Crickmore/Bt/). Proteins encoded by the cry 2 gene family have a molecular weight between 65 and $71 \mathrm{kDa}$ and 
form cuboidal crystals (Hofte and Whiteley 1989). There are five known subgroups of the cry2A gene family, cry $2 \mathrm{Aa}$ (Donovan et al. 1988), cry2Ab (Widner and Whiteley 1989), cry2Ac (Zhang et al. 2007), cry2Ad (Genebank: AF200816) and cry2Ae (Genebank: AAQ52362). The Cry2Aa and Cry2Ac proteins have known activity to lepidoptera and diptera insects, while Cry2 $\mathrm{Ab}$ is known to be toxic only to lepidoptera insects (Bravo 2004; Zhang et al. 2007).

Baculovirus are insect viruses that have been used as safe biological control agents (Moscardi 1999) and expression vectors for heterologous genes in insect cells (Jarvis 1997). One of the advantages of baculovirus as an expression vector in insect cells is the high levels of the heterologous proteins produced, mainly due to the presence of strong promoters which are active during the late phase of infection (Szewczyk et al. 2006; Lu and Miller 1997). The crylAb and crylAc genes have been inserted into the genome of a baculovirus with the aim of improving the viral speed of kill as well as its pathogenicity to insect pests (Martens et al. 1990; Merryweather et al. 1990; Pang et al. 1992; Ribeiro and Crook 1993, 1998; Chang et al. 2003). Besides that, the crylCa and crylla genes were also introduced into baculovirus genomes for toxicity studies of individually expressed recombinant Cry proteins (Aguiar et al. 2006; Martins et al. 2008).

The aims of this study were the expression of the Cry2Aa and Cry2Ab proteins in insect cells using the baculovirus expression system and the toxicity analysis of the heterologous proteins against Lepidopeteran (Anticarsia gemmatalis and Spodoptera frugiperda) and Dipteran (Aedes aegypti and Culex quinquefasciatus) larvae.

\section{Materials and methods}

\section{Cells, viruses and bacteria}

Trichoplusia ni (BTI-Tn5B1-4) cells were maintained at $27^{\circ} \mathrm{C}$ in TC-100 medium supplemented with $10 \%$ fetal bovine serum (Gibco-BRL) and served as host for the wild type virus AcMNPV, the recombinant viruses vSynVI'gal (Wang et al. 1991), vAcCry2Aa and vSynCry2Ab (constructed in this work). B. thuringiensis subsp. kurstaki S447 (Btk) was obtained from the Bacillus ssp. Bank of the Embrapa Recursos Genéticos and Biotecnologia (Brasília, Brazil).

Recombinant virus construction

The complete ORFs of the cry2Aa and cry $2 A b$ genes from $B$. thuringiensis subsp. kurstaki S447 were amplified by PCR using specific oligonucleotide primers (cry2AaForward-5'-GGGATCCATGAATAATGTATTGAATAGTG
GAAG-3'; cry2AaReverse-5'-GGGATCCTTAATAAAG TGGTGGAAGATTAGTTGGC- $3^{\prime}$ ), (cry2AbForward- $5^{\prime}$ GGGATCCATGAATAATGTATTGAATAGTGGAAG-3' e cry2AbReverse-5'-GGGATCCTTAATAAAGTGGTG GAAGATTAGTTGGC- $-3^{\prime}$ ). The underline shows the sequence of the Bam $\mathrm{HI}$ restriction site and the $A T G$ represent the start codon of each gene. The following PCR program was used for the two sets of oligonucleotides: $95^{\circ} \mathrm{C} / 1 \mathrm{~min}$ and 31 cycles of $95^{\circ} \mathrm{C} / 1 \mathrm{~min}, 52^{\circ} \mathrm{C} / 1: 30 \mathrm{~min}, 72^{\circ} \mathrm{C} / 1 \mathrm{~min}$ and a final extension of $72^{\circ} \mathrm{C} / 1 \mathrm{~min}$. Amplified fragments were cloned into the pGem ${ }^{\circledR}-\mathrm{T}$ easy vector (Promega), using Escherichia coli DH5 $\alpha$ (Invitrogen) as a host, following the manufacturer's instructions. DNA from recombinant plasmids pGemcry2Aa and pGemcry2Ab were purified (Sambrook et al. 1989) and sequenced (377-Applied Biosystem). The plasmid pGemcry2Aa was digested with $B a m \mathrm{HI}$ and pGemcry2Ab with EcoRI and separated in a $0.8 \%$ agarose gel. The two DNA fragments of around $1,900 \mathrm{bp}$ were purified using the Purelink Gel Extraction Kit (Invitrogen). The cry2Aa gene was then cloned into the pFastbac $1{ }^{\circledR}$ (Invitrogen), while cry $2 A b$ into the pSynXIVVI+X3 (Wang et al. 1991), previously digested with $B a m \mathrm{HI}$ and EcoRI, respectively. The recombinant plasmid pFastcry2Aa was transformed into E. coli DH10Bac ${ }^{\mathrm{TM}}$ (Invitrogen), following the bac-to-bac kit instructions (Invitrogen). The insertion of the cry2Aa gene into the genome of the bacmid was confirmed by PCR with specific oligonucleotides, according to the manufacturer's instructions (Invitrogen). The DNA of recombinant bacmid was transfected into BTI-Tn5B1-4 cells using liposomes following the manufacturer's instructions (Cellfectin ${ }^{\circledR}$ Invitrogen) and the recombinant virus amplified (see below). On the other hand, the pSyncry2 Ab plasmid $(1 \mu \mathrm{g})$ was cotransfected with vSynVI-gal DNA $(0.5 \mu \mathrm{g})$, previously linearized with the restriction enzyme Bsu36 I into insect cells using liposomes as described above. The plates were incubated one week, and the recombinant virus purified through end-point dilution in 96-well plates (O'Reilly et al. 1992). Recombinant viruses were amplified in $75 \mathrm{~cm}^{2}$ plates (TPP) containing $5 \times 10^{6}$ cells and viral DNA from the two viruses was purified (O'Reilly et al. 1992). The presence of the heterologous genes were confirmed by PCR using specific oligonucleotides as described above.

Heterologous protein expression

BTI-Tn5B1-4 $\left(10^{6}\right)$ cells were infected with recombinant and wild-type AcMNPV viruses (10 pfu/cell) and observed by light microscopy. At 120 h.p.i., cells were collected by centrifugation $(5.000 \times \mathrm{g} / 10 \mathrm{~min})$ and stored at $-80^{\circ} \mathrm{C}$. Third instar $S$. frugiperda larvae were infected by injection of $10 \mu \mathrm{l}$ of viral stocks $\left(10^{8} \mathrm{pfu} / \mathrm{ml}\right.$, vAcCry2Aa and AcMNPV; $10^{7} \mathrm{pfu} / \mathrm{ml}$ vSynCry2Ab) into the hemolymph. 
Total infected larvae extracts (120 h.p.i) were analysed in a $12 \%$ SDS-PAGE (Mini-protean II-Biorad) following the manufacturer's instruction. A band around $65 \mathrm{kDa}$ on SDSPAGE was quantified by using the densitometry program Image Phoretix 2D (Pharmacia). The purification of protein crystals was carried out by ultracentrifugation of dead virus infected $S$. frugiperda larvae on a discontinuous sucrose gradient as described elsewhere (Thomas and Ellar 1983; O'Reilly et al. 1992). The purified crystals from vAcCry2Aa-infected larvae and the crystals co-purified with the virus occlusion bodies from vSynCry2Ab-infected larvae were solubilized with $0.1 \mathrm{M} \mathrm{Na}_{2} \mathrm{CO}_{3} \mathrm{pH} 10.5$ at $37^{\circ} \mathrm{C} / 1 \mathrm{~h}$ and neutralized with $0.1 \mathrm{M}$ Tris- $\mathrm{HCl}, \mathrm{pH} 7.5$ (Bravo et al. 2001). The proteins were analysed in a $12 \%$ SDS-PAGE as described above and the amount of solubilized protein was measured with the Bradford reagent, following the manufacturer's instructions $\left(\mathrm{BioRad}^{\circledR}\right)$.

Structural and ultrastructural analysis of purified putative Cry2Aa and Cry2Ab protein crystals

Ultrastructural analysis of the purified recombinant Cry2A crystal protein and co-purified Cry $2 \mathrm{Ab}$ crystal protein and viral occlusion bodies were carried in a light microscope (Axiphot, Zeiss) and a Zeiss DSM962 scanning electron microscope at $10 \mathrm{Kv}$ and $20 \mathrm{Kv}$.

\section{Bioassays}

Different doses of the total insect extracts containing Cry2Aa crystals and a mixture of Cry $2 \mathrm{Ab}$ crystals and viral occlusion bodies (30 $\mu \mathrm{l}$ containing 30, 20, 15, 10, 5 and $1 \mu \mathrm{g} / \mathrm{ml}$, respectively) were spread over insect diet in 24 wells plates, each containing a second-instar larvae $(S$. frugiperda or A. gemmatalis). Second instar A. aegypti and Culex quinquefasciatus larvae were also used in a bioassay with the total insect extract and solubilized heterologous Cry2Aa crystals. The bioassay was carried out in plastic cups with 25 larvae in $100 \mathrm{ml}$ of water containing the same doses cited above. B. thuringiensis subsp. kurstaki HD-1 was used as a reference for lepidoptera toxicity. The bioassay was repeated three times. After photophase incubation (14/10 h) during $120 \mathrm{~h}$ (lepidopteran lavae) and 24 and $48 \mathrm{~h}$ (dipteran larvae), the $50 \%$ lethal concentration $\left(\mathrm{LC}_{50}\right)$ was estimated by probit analysis (Finney 1971).

\section{Results and discussion}

Amplification, cloning and sequencing of $\operatorname{cry} 2 \mathrm{~A}$ genes

The DNA fragments containing the cry $2 A a$ and $c r y 2 A b$ genes (around 1,900 bp) from the Brazilian S477 strain of
B. thuringiensis subsp. kurstaki were amplified by PCR and cloned into the pGem ${ }^{\circledR}$-T easy vector (not shown), resulting in the recombinant plasmids pGemcry2Aa and pGemcry $2 \mathrm{Ab}$. The DNA fragments were sequenced and the sequence analysis revealed that both contained ORFs of $1,902 \mathrm{bp}$ coding for putative proteins of 633 aminoacids. Blast analysis of the pGemcry2Aa DNA sequence shows that this sequence is identical to $c r y 2 \mathrm{Aa}$ gene described by Donovan et al. (1988) (Genebank = M31738), with only one nucleotide base different at position 576 (change of a $\mathrm{T}$ to a $\mathrm{C}$ ). However, this difference did not change the codon for the amino acid 192 (isoleucine, ATT to ATC). The pGemcry $2 \mathrm{Ab}$ DNA sequence showed $100 \%$ identity with the $c r y 2 A b$ gene described by Dankocsik et al. (1990) $($ Genebank $=$ CAA39075.1).

\section{Construction of recombinant baculoviruses}

DNA fragments containing the cry $2 A a$ and $c r y 2 A b$ genes were cloned into the transfer vectors pFastbac $1^{\circledR}$ and pSynXIVVI ${ }^{+} \mathrm{X} 3$, respectively (Fig. 1). The cry $2 A a$ and $c r y 2 A b$ genes were inserted into the genome of the baculovirus AcMNPV and the recombinant viruses vAcCry2Aa and vSynCry $2 \mathrm{Ab}$ were constructed. The vSynCry $2 \mathrm{Ab}$ virus, besides having a cry gene, has the AcMNPV polyhedrin gene, which make easy the purification of the recombinant by the presence of viral occlusion bodies (polyhedra) inside the nucleus of infected cells. In order to confirm the insertion of the heterologous gene into the recombinant virus genome, $\mathrm{PCR}$ reactions were carried out with cry-specific oligonucleotides (not shown).

\section{Heterologous protein expression analysis}

Extracts of wild type and recombinant viruses-infected larvae were analysed by SDS-PAGE (Fig. 2). The heterologous Cry $2 \mathrm{~A}$ and $\mathrm{Cry} 2 \mathrm{Ab}$ proteins were expressed in insects since we have detected a major protein band of around $65 \mathrm{kDa}$ by SDS-PAGE in infected insect extracts and more bands corresponding to proteins from the insect cadaver (Fig. 2, lanes 3-4). We also analysed purified and solubilized AcMNPV occlusion bodies (Fig. 2, lane 5), heterologous CryAa crystals (Fig. 2, lane 6) and co-purified and solubilized heterologous CryAb crystals and viral occlusion bodies (Fig. 2, lane 7). Two main bands of 60 and $65 \mathrm{kDa}$, respectively were detected by SDS-PAGE and probably correspond to different forms of the Cry $2 \mathrm{Aa}$ and $\mathrm{Cry} 2 \mathrm{Ab}$ proteins. Another protein of $29 \mathrm{kDa}$ was also detected in the extracts of insects infected with wild-type AcMNPV and vSynCry2Ab (Fig. 2, lanes 2 and 4, respectively). Besides that, purified and solubilized AcMNPV occlusion bodies and Cry $2 \mathrm{Ab}$ crystals co-purified with viral occlusion bodies also showed the same $29 \mathrm{kDa}$ 


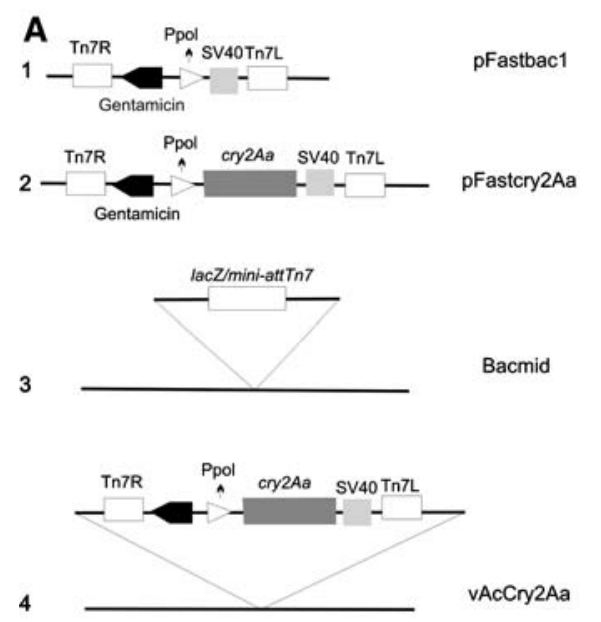

Fig. 1 Diagram showing the different plasmids and viruses used in this work. (a) 1-plasmid pFastbac $1^{\circledR}$ (Invitrogen), 2-plasmid pFastcry $2 A a$ containing the cry $2 A a$ gene cloned after the polyhedrin promoter in the pFastbac $1^{\circledR}$ plasmid, 3-Region of the baculovirus AcMNPV genome (in the form of a bacmid) where the heterologous genes are inserted after transposition inside E. coli strain DH10-Bac (Invitrogen) encoding the lac $Z$ gene from a pUC-based cloning vector. Inserted into the $\mathrm{N}$-terminus of the lac $\mathrm{Z}$ gene, is a short segment containing the attachment site for the bacterial transposon $\operatorname{Tn} 7$ (mini-att $\operatorname{Tn} 7$ ), 4-Region of the recombinant virus vAcCry2Aa genome where the cry2Aa gene was inserted after transposition. (b) plasmid pSynXIVVI $+\mathrm{X} 3$ containing the polyhedrin promoter

band (Fig. 2, lanes 5 and 7, respectively), which corresponds to polyhedrin, the main occlusion body protein of baculovirus. The cry 2 genes codify for Cry 2 proteins with a putative molecular mass around $70 \mathrm{kDa}$ and accumulate in B. thuringiensis as cuboidal crystals (Widner and Whiteley 1989; Yamamoto and McLaughlin 1981). The difference in molecular mass for the heterologous Cry2Aa and Cry2Ab proteins in SDS-PAGE could be due to degradation by proteases present in the insect cadaver. Park et al. (1999) and Iriarte et al. (2000) also found a $65 \mathrm{kDa}$ protein band in SDS-PAGE corresponding to the Cry2Aa protein expressed in B. thuringiensis. Recently, Aguiar et al. (2006) have also detected a possible protease processed $65 \mathrm{kDa}$ protein band by SDS-PAGE in a recombinant baculovirus infectedinsect extracts containing a truncated version of the Cry1Ca protein. Cry proteins from B. thuringiensis are usually synthesized as large precursors (protoxins), which are cleaved by insect gut proteases to form active toxins of around $65 \mathrm{kDa}$ (Höfte and Whiteley 1989).

Structural and ultrastructural analysis of insect cells and insects infected with the recombinant viruses

T. $n i$ (BTI-Tn5B1-4) cells infected with the recombinant viruses were analysed for the presence of possible Cry protein crystals inside the cells cytoplasm. No crystals were detected inside BTI-Tn5B1-4 cells by light microscopy
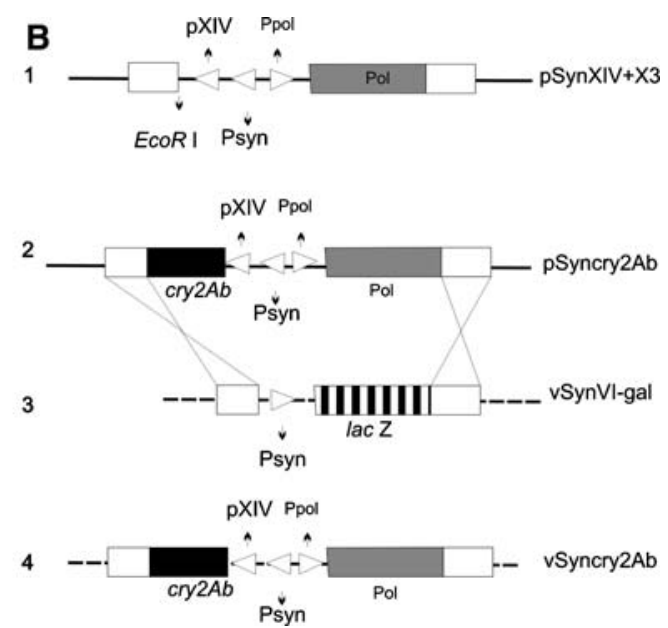

(Ppol), a mutated promoter derived from polyhedrin promoter (PXIV), a synthetic promoter (PSyn) and the polyhedrin gene (Pol), 2 -plasmid pSyncry $2 \mathrm{Ab}$, showing the cry $2 \mathrm{Ab}$ gene inserted at the EcoRI site of the pSynXIVVI + X3 plasmid, 3-region of the vSynVI'gal virus genome where heterologous genes are inserted after homologous recombination with transfer vectors based on the pSynXIVVI + X3 plasmid, 4-region of the recombinant vSyn$\mathrm{Cry} 2 \mathrm{Ab}$ virus genome where the $c r y 2 A b$ gene was inserted. The $c r y 2 A b$ was cloned into the plasmid pSynXIVVI $+\mathrm{X} 3$ generating the pSyncry2 $\mathrm{Ab}$ plasmid that was co-transfected with vSynVI'gal DNA into insect cells, generating the recombinant virus vSynCry $2 \mathrm{Ab}$ by homologous recombination

(not shown). However, the sucrose gradient purified samples from extracts of larvae infected with both recombinant viruses showed the presence of large cuboidal crystals (Fig. 3). These crystals were larger and had the same cuboidal shape as the ones found in $B$. thuringiensis strains containing cry2Aa and cry2Ab genes (Yamamoto et al. 1981; Widner and Whiteley 1989). This difference in the size of the crystal when expressed in insects may be related to the differences in the size of the cells where the protein is being expressed (Ribeiro and Crook 1993). Aguiar et al. (2006) have shown the formation of large cuboidal crystals of a truncated version of the Cry1Ca protein in the cytoplasm of BTI-Tn5B1-4 cells infected with a recombinant baculovirus carrying a $\mathrm{cry} \mathrm{lC}$ a truncated gene. On the other hand, Ribeiro and Crook (1993) did not detect the formation of crystals of Cry1Ac in S. frugiperda cells in culture (Sf21), but only in Heliothis virescens larvae.

The C-terminal portion of B. thuringiensis $135 \mathrm{kDa}$ Cry proteins like Cry1A, Cry4A and Cry4B, is known to be important in the formation of crystals (Baum and Malvar 1995; Aronson 1994). This region of Cry proteins contains more cysteine residues, which some authors correlate to crystal formation, since they are responsible for disulfide bond formation and have been suggested to be important in the formation of such crystals (Ge et al. 1998; Bietlot et al. 1990). However, smaller Cry proteins such as Cry2A and Cry11A do not have the C-terminal portion and some 


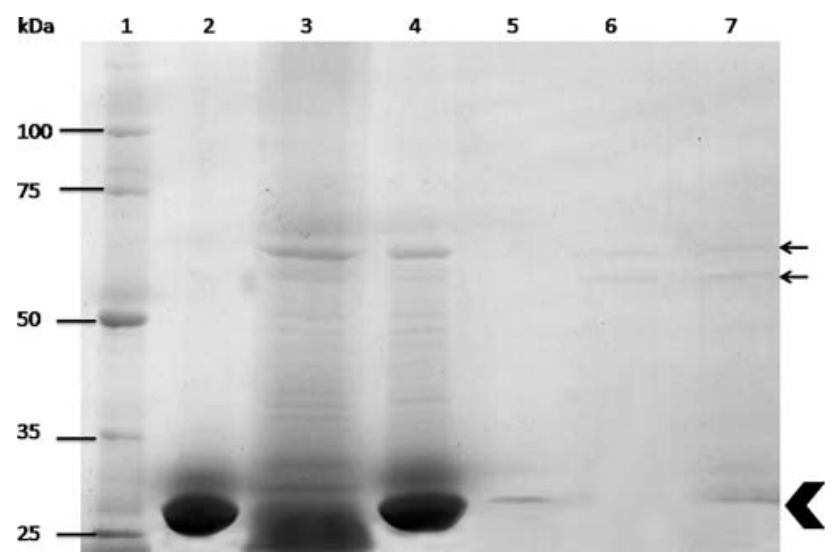

Fig. 2 Expression analysis of the heterologous proteins Cry2Aa and $\mathrm{Cry} 2 \mathrm{Ab}$ in insects infected with the recombinant viruses vAcCry2Aa and vSynCry2Ab. SDS-PAGE (12\%) showing in 1-Molecular Weight Marker (Broad Range Protein Molecular Weight MarkerPromega), 2-Viral occlusion bodies (polyhedra) from total extracts of $S$. frugiperda larvae infected with the wild type virus AcMNPV showing the $29 \mathrm{kDa}$ polyhedrin protein band (large arrow), 3-Total extracts of $S$. frugiperda larvae infected with the vAcCry2Aa virus showing one main band of $65 \mathrm{kDa}$ (upper small arrow) and other proteins from the insect cadaver, 4-Total extracts of $S$. frugiperda larvae infected with the vAcCry $2 \mathrm{Ab}$ virus showing one main band of $65 \mathrm{kDa}$ (upper small arrow), the $29 \mathrm{kDa}$ polyhedrin protein band (large arrow) and other proteins from the insect cadaver, 5-Purified and solubilized polyhedra from the wild type virus AcMNPV showing the $29 \mathrm{kDa}$ polyhedrin protein band (large arrow), 6-Purified and solubilized Cry2Aa crystals from vAcCry2Aa-infected $S$. frugiperda extracts showing two main bands of around 60 and $65 \mathrm{kDa}$, respectively (small arrows), 7-Purified and solubilized Cry2Ab crystals from vAcCry $2 \mathrm{Ab}$-infected $S$. frugiperda extracts showing two main bands of around 60 and $65 \mathrm{kDa}$, respectively (small arrows) and the $29 \mathrm{kDa}$ polyhedrin protein band (large arrow)

authors showed evidence that these proteins rely on accessory proteins (ORF2 and P20, respectively) for the formation of crystals (Crickmore and Ellar 1992; Crickmore et al. 1994). In B. thuringiensis, the cry2Aa operon presents, besides the cry $2 A a$ gene, two more ORFs, orf1 and orf2. ORF2 protein was shown to act as a helper protein for Cry2Aa crystallization while the role of ORF1 is not well understood (Crickmore and Ellar 1992; Crickmore et al. 1994; Sasaki et al. 1997; Staples et al. 2001). Therefore, the formation of Cry2Aa and Cry2Ab crystals in insects may be due to the presence of different cellular protein present in insect cells which possibly can act as chaperones helping the correct folding of both crystal proteins. We have noted that crystals of different sizes were produced in insects infected with the recombinant viruses (Fig. 3).

\section{Bioassays}

The heterologous Cry2Aa and Cry2Ab proteins present in the recombinant viruses infected-insect extracts were shown to be toxic to second instar A. gemmatalis with a
$\mathrm{LC}_{50}$ of $1.03 \mu \mathrm{g} / \mathrm{ml}(0.082-2.621)$ and $S$. frugiperda $\mathrm{LC}_{50}$ of $3.45 \mu \mathrm{g} / \mathrm{ml}(0.105-11.26)$ larvae, respectively. No toxic activity was detected for second instar A. aegypti, $C$. quinquefasciatus and second instar S. frugiperda larvae when incubated with the heterologous Cry2Aa protein and for second instar A. gemmatalis when incubated with the Cry2 $\mathrm{Ab}$ protein (data not shown). B. thuringiensis subsp. kurstaki HD-1 showed a $\mathrm{LC}_{50}$ of $2.32 \mu \mathrm{g} / \mathrm{ml}(0.041-11.85)$ and 3.457 (0.711-15.08) to A. gemmatalis and S. frugiperda, respectively. The heterologous Cry2Aa and Cry2Ab proteins showed similar $\mathrm{LC}_{50}$ values to $\mathrm{A}$. $\mathrm{gem}$ matalis (Cry2Aa) and $S$. frugiperda (Cry2Ab) when compared to the $\mathrm{LC}_{50}$ values of the Btk strain for the same insects. The Btk strain has besides the Cry2Aa and Cry $2 \mathrm{Ab}$ toxins, others Cry proteins that have toxic activity to different insects and might interfere with the toxicity to different insects (Lereclus et al. 1989). These proteins could act synergistically to potentiate the toxicity by binding to different midgut receptors in the same insect or antagonistically by competing for the same receptor (Aronson et al. 1991; de Maagd et al. 2001; Rasko et al. 2005; Bravo et al. 2007; Pérez et al. 2007; Soberón et al. 2007). The Cry $2 \mathrm{Ab}$ protein shows $87 \%$ of amino acid sequence identity with the Cry2Aa protein, but differs in toxicity. Although the literature describes Cry2Aa as having toxic activity to both Lepidopteran and Dipteran insects (Widner and Whiteley 1989), we have not detected Cry2Aa toxicity against dipteran larvae. Both, total Cry2A-infected insect extracts and purified alkali-solubilized Cry2Aa crystals failed to kill second instar A. aegypti and $C$. quinquefasciatus. Park et al. (1999) have detected no toxicity or very low toxicity of purified Cry2Aa crystals to $A$. aegypti from recombinant $B$. thuringiensis strains. Dankocsik et al. (1990) also have not found Cry2Ab toxicity to Diptera (A. aegypti), but demonstrated a high toxicity against $H$. zea. When Cry proteins are expressed in insect larvae, other proteases present in the insect cadaver might process the Cry protein in a different manner than the midgut proteases and have a further influence on the toxic activity (Ribeiro and Crook 1993). The alkaline environment of the insect midgut as well as crystal composition are important factors for determination of Cry protein specificity (Choma and Kaplan 1990; Aronson et al. 1991).

The use of baculovirus and insect cells to express Cry proteins is an alternative strategy to produce these proteins at high levels for synergistic studies between different toxins. Previous works have shown that Cry proteins can act synergistically increasing their toxicity towards susceptible insects (Crickmore et al. 1995; Wirth et al. 2000, 2001; Xue et al. 2005). Since insect cells infected with recombinant baculoviruses containing cry gene produce crystals similar to crystals produced in B. thuringiensis, 
Fig. 3 Structural and ultrastructural analysis of purified viral occlusion bodies and/or crystals from $S$. frugiperda larvae infected with the recombinant viruses vAcCry2Aa and vSynCry2Ab by light (1 and 3 ) and scanning electron microscopy (2 and 4). The figure shows cuboidal crystals (Cry) of the heterologous proteins Cry2Aa (1 and 2) and Cry2Ab (3 and 4) and the presence of viral occlusion bodies (polyhedra, $\mathrm{P}$ ) (3 and 4)
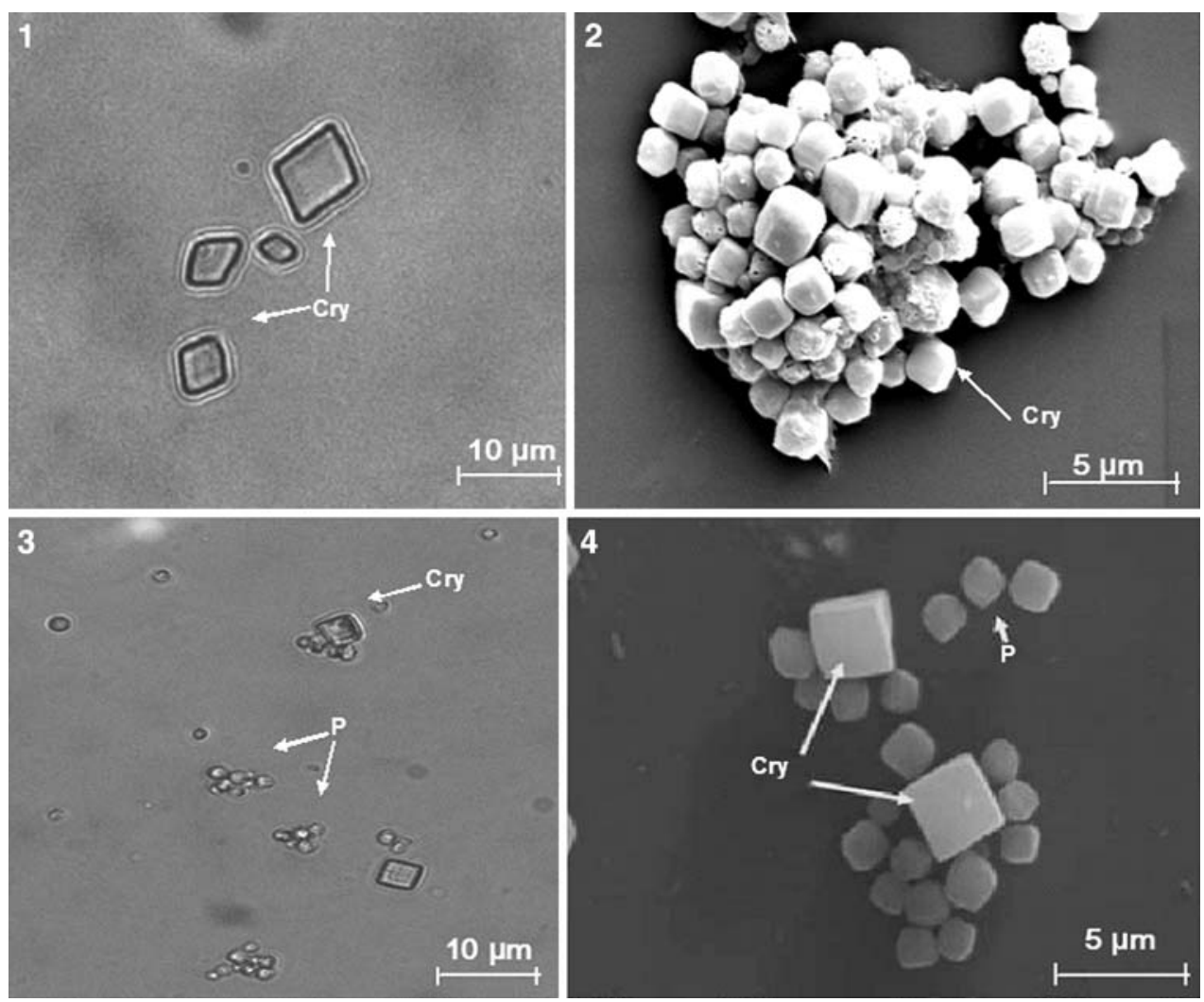

structural studies may also be facilitated, since these proteins can be studied isolated without the contamination of other Cry proteins which is commonly found in $B$ thuringiensis strains (Pang et al. 1992; Ribeiro and Crook 1993). Furthermore, other baculoviruses than AcMNPV, could be enginnered to carry cry genes and be used as improved biopesticides to important agricultural pests (Chang et al. 2003).

The first transgenic plant containing a cry gene constructed was tobacco back in the late 1980's (Höfte et al. 1986; Vaeck et al. 1987). In 2005, transgenic Bt corn and cotton represented $11.1 \%$ and $33.6 \%$, respectively of global plantings of these crops (http://www.pgeconomics.co.uk/ pdf/global_impactstudy_2006_v1_finalPGEconomics.pdf) representing an important tool for the control of lepidopteran pests (Zhao et al. 2005). Since insects have the potential to develop resistance to Cry proteins (Ferre and van Rie 2002; Sarfraz 2004) and the expression of different Cry proteins in the same plant can reduce or delay the onset of resistance (Zhao et al. 2003), the search for new Cry proteins and their study are important strategies to construct a bank of possible candidates for introduction into economically important crops (Schnepf et al. 1998).

Acknowledgements We are grateful to Embrapa Recursos Genéti$\cos$ e Biotecnologia for supplying insect larvae. This work was supported by the following Brazilian agencies: PRONEX, FAPDF, CNPq, FINATEC and CAPES.

\section{References}

Aguiar RWS, Martins ES, Valicente FH, Carneiro NP, Batista AC, Melatti VM et al (2006) A recombinant truncated Cry $1 \mathrm{Ca}$ protein is toxic to lepidopteran insects and forms large cuboidal crystals in insect cells. Curr Microbiol 53:287-292. doi: 10.1007/s00284-005-0502-3

Aronson AI (1994) Flexibility in protoxins composition of Bacillus thuringiensis. FEMS Microbiol Lett 117:21-28. doi:10.1111/ j.1574-6968.1994.tb06737.x

Aronson AI, Han E, McGaughey W, Johnson D (1991) The solubility if the inclusion proteins from Bacillus thuringiensis is depend upon protoxin composition and is a factoring toxicity to insects. Appl Environ Microbiol 57:981-986

Baum JA, Malvar T (1995) Regulation of insecticidal crystal protein production in Bacillus thuringiensis. Mol Microbiol 18:1-12. doi:10.1111/j.1365-2958.1995.mmi_18010001.x

Bietlot HP, Vishnubhatla I, Carey PR, Pozsgay M, Kaplan H (1990) Characterization of the cysteine residues and disulphide linkages in the protein crystal of Bacillus thuringiensis. Biochem $\mathbf{J}$ 267:309-315

Bravo A (2004) Familia de proteínas inseticidas de Bacillus thuringiensis. In: Bravo A, Ceron J (eds) Bacillus thuringiensis en el control biológico. Editorial Buena Semilla, Bogotá, pp 4968

Bravo A, Arrieta G, Benintende G, Real MD, Espinoza AM, Ibarra J et al (2001) Metodologias utilizadas en investigación sobre bactérias entomopatógenas. Unam, México

Bravo A, Gill SS, Soberón M (2007) Mode of action of Bacillus thuringiensis Cry and Cyt toxins and their potential for insect control. Toxicon 49:423-435. doi:10.1016/j.toxicon.2006.11.022

Chang JH, Choi JY, Jin BR, Roh JY, Olszewski A, Seo SJ et al (2003) An improved baculovirus insecticide producing occlusion bodies 
that contain Bacillus thuringiensis insect toxin. J Invertebr Pathol 84:30-37. doi:10.1016/S0022-2011(03)00121-6

Choma CT, Kaplan H (1990) Folding and unfolding of the protoxin from Bacillus thuringiensis: evidence that the toxic moiety is present in an active conformation. Biochemistry 29:1097110977. doi:10.1021/bi00501a015

Crickmore N, Ellar DJ (1992) Involvement of possible chaperonin in the efficient expression of a cloned CryIIA delta-endotoxin gene in Bacillus thuringiensis. Mol Microbiol 6:1533-1537. doi: 10.1111/j.1365-2958.1992.tb00874.x

Crickmore N, Wheeler VC, Ellar DJ (1994) Use of an operon fusion to induce expression and crystallization of a Bacillus thuringiensis delta endotoxin enconded by a cryptic gene. Mol Gen Genet 242:365-378. doi:10.1007/BF00280428

Crickmore N, Bone EJ, Williams JA, Ellar DJ (1995) Contribution of the individual components of the delta-endotoxin crystal to the mosquitocidal activity of Bacillus thuringiensis subsp. israelensis. FEMS Microbiol Lett 131:249-254

Crickmore N, Zeigler DR, Feitelson J, Schnepf E, Van Rie J, Lereclus $\mathrm{D}$ et al (1998) Revision of the nomenclature of the Bacillus thuringiensis pesticidal crystal proteins. Microbiol Mol Biol Rev 62:807-813

Dankocsik C, Donovan WP, Jany CS (1990) Activation of a cryptical crystal protein gene of Bacillus thuringiensis subspecies kurstaki by gene fusion and determination of crystal protein insecticidal specificity. Mol Microbiol 4:2087-2094. doi:10.1111/j.13652958.1990.tb00569.x

de Maagd RA, Bravo A, Crickmore N (2001) How Bacillus thuringiensis has evolved specific toxins to colonize the insect world. Trends Genet 17:193-199. doi:10.1016/S0168-9525 (01)02237-5

Donovan WP, Dankocsik CC, Gilbert MP, Gawron-Burke MC, Groat RG, Carlton BC (1988) Amino acid sequence and entomocidal activity of the $\mathrm{P} 2$ crystal protein. An insect toxin from Bacillus thuringiensis var. kurstaki. J Biol Chem 263:561-567

El-Bendary (2006) Bacillus thuringiensis and Bacillus sphaericus biopesticides production. J Basic Microbiol 46:158-170

Estruch JJ, Carozzi NB, Desai N, Nicholas B, Duck NB, Warren GW, Koziel MG (1997) Transgenic plants: an emerging approach to pest control. Nat Biotecnol 15:137-141

Ferre J, van Rie J (2002) Biochemistry and genetics of insect resistance to Bacillus thuringiensis. Ann Rev Entomol 47:501533

Finney DJ (1971) Probit analysis. Cambridge University Press, Cambridge

Ge B, Bideshi D, Moar JW, Federici BA (1998) Diferential effects of helper proteins encoded by the cry $2 A$ and $c r y 11 A$ operons on the formation of Cry2A inclusions in Bacillus thuringiensis. FEMS Microbiol Lett 165:35-41

Höfte H, Whiteley HR (1989) Insecticidal crystal proteins of Bacillus thuringiensis. Microbiol Rev 53:242-255

Höfte H, de Greve H, Seurinck J, Jansens S, Mahillon J, Ampe C, Vandekerckhove J, Vanderbruggen H, van Montagu M, Zabeau M (1986) Structural and functional analysis of a cloned delta endotoxin of Bacillus thuringiensis berliner 1715. Eur J Biochem 161:273-280

Iriarte J, Porcar M, Lecadet M, Caballero P (2000) Isolation and characterization of Bacillus thuringiensis strains from aquatic environments in Spain. Curr Microbiol 40:402-408

Jarvis DL (1997) Baculovirus expression vectors. In: Miller LK (ed) The baculovirus. Plenum, New York, pp 341-389

Lereclus D, Bourgouin C, Lecadet MM, Klier A, Rapoport G (1989) Role, structure and molecular organization of the genes coding for the parasporal $\delta$-endotoxins of Bacillus thuringiensis. In: Smith I, Slepecky RA, Setlow P (eds) Regulation of procaryotic development: structural and functional analysis of bacterial sporulation and germination. American Society for Microbiology, Washington, pp 255-276

Lu A, Miller LK (1997) Regulation of baculoviruses late and very late expression. In: Miller LK (ed) The baculoviruses. Plenum Press, New York, pp 193-216

Martens JW, Honéee G, Zuidema D, Van Lent JWM, Visser B, Vlak JM (1990) Insecticidal activity of a bacterial crystal protein expressed by a recombinant baculovirus in insect cells. Appl Environ Microbiol 56:2764-2770

Martins ES, Aguiar RW, Martins NF, Melatti VM, Falcão R, Gomes AC, Ribeiro BM, Monnerat RG (2008) Recombinant Cry1Ia protein is highly toxic to cotton boll weevil (Anthonomus grandis Boheman) and fall armyworm(Spodoptera frugiperda). J Appl Microbiol 104:1363-1371

Merryweather AT, Weyer U, Harris MPG, Hirst M, Booth T, Possee D (1990) Construction of genetically engineered baculovirus insecticides containing the Bacillus thuringiensis subsp. kurstaki HD-73 delta-endotoxin. J Gen Virol 71:1535-1544

Moscardi F (1999) Assessment of the application of baculoviruses for control of Lepidoptera. Annu Rev Entomol 44:257-289

O'Reilly DR, Miller LK, Luckow VA (1992) Baculovirus expression vectors: a laboratory manual. Freeman, New York

Pang Y, Frutos R, Federici BA (1992) Synthesis and toxicity of full length and truncated bacterial CryIVD mosquitocidal proteins expressed in lepidopteran cells a baculovírus vector. J Gen Virol 73:89-101

Park H, Bideshi DK, Johnson JJ, Federici BA (1999) Diferential enhancement of Cry2A versus Cry11A yields in Bacillus thuringiensis by use of the cry3A STAB mRNA sequence. FEMS Microbiol Lett 181:319-327

Pérez C, Muñoz-Garay C, Portugal LC, Sánchez J, Gill SS, Soberón M, Bravo AC (2007) Bacillus thuringiensis ssp. israelensis Cyt1Aa enhances activity of Cry11Aa toxin by facilitating the formation of a pre-pore oligomeric structure. Cell Microbiol 9:2931-2937

Rasko DA, Altherr MR, Han CS, Ravel J (2005) Genomics of the Bacillus cereus group of organisms. FEMS Microbiol Rev 29:303-329

Ribeiro BM, Crook NE (1993) Expression of full length and truncated forms of crystal protein genes from Bacillus thuringiensis subsp. kurstaki in baculovírus and pathogenicity of the recombinant viruses. J Invertebr Pathol 62:121-130

Ribeiro BM, Crook NE (1998) Construction of occluded recombinant baculoviruses containing the full-length cry $1 \mathrm{Ab}$ and cry $1 \mathrm{Ac}$ genes from Bacillus thuringiensis. Braz J Med Biol Res 31:763769

Sambrook J, Fritsch EF, Maniatis T (1989) Molecular cloning: a laboratory manual, 3rd edn. Cold Spring Harbor, New York

Sarfraz M (2004) Interaction between diamondback moth and Bacillus thuringiensis. Outlooks Pest Manag 15:167-171

Sasaki J, Asano S, Hashimoto N, Lay BW, Hastowo S, Bando H, Iizuka T (1997) Characterization of a cry $2 A$ gene cloned from an isolate of Bacillus thuringiensis serovar sotto. Curr Microbiol $35: 1-8$

Schnepf E, Crickmore N, Van Rie J, Lereclus D, Baum J, Feitelson J, Zeigler DR, Dean DH (1998) Bacillus thuringiensis and its pesticidal crystal proteins. Microbiol Mol Biol Rev 62:775-806

Soberón M, Fernández LE, Pérez C, Gill SS, Bravo A (2007) Mode of action of mosquitocidal Bacillus thuringiensis toxins. Toxicon 49:597-600

Staples N, Ellar D, Crickmore N (2001) Cellular localization and characterization of the Bacillus thuringiensis Orf 2 crystalization factor. Curr Microbiol 42:388-392

Szewczyk B, Hoyos-Carvajal L, Palusek M, Skrzecz I, Lobo de Souza M (2006) Baculoviruses- re-emerging biopesticides. Biotech Adv 24:143-160 
Thomas WE, Ellar DJ (1983) Mechanism of action of Bacillus thuringiensis var israelensis delta-endotoxin. FEBS Lett 154:362-368

Vaeck M, Reynaerts A, Hofte A, Jansens S, De Beuckeleer M, Dean C, Zabeau M, Van Montagu M, Leemans J (1987) Transgenic plants protected from insect attack. Nature 328:33-37

Wang X, Ooi BG, Miller LK (1991) Baculovirus vectors for multiple gene expression and for occluded virus production. Gene 100:131-137

Widner WR, Whiteley HR (1989) Two highly related instecidal crystal proteins of Bacillus thuringiensis subsp kurstaki possess different host range specificities. J Bacteriol 171: 965-974

Wirth MC, Federici BA, Walton WE (2000) Cyt1A from Bacillus thuringiensis synergizes activity of Bacillus sphaericus against Aedes aegypti. Appl Environ Microbiol 66:1093-1097

Wirth MC, Delécluse A, Walton WE (2001) Cyt1Ab1 and Cyt2Ba1 from Bacillus thuringiensis subsp. medellin and B. thuringiensis subsp. israelensis synergize Bacillus sphaericus against Aedes aegypti and resistant Culex quinquefasciatus (Diptera: Culicidae). Appl Environ Microbiol 67:3280-3284
Xue JL, Cai QX, Zheng DS, Yuan ZM (2005) The synergistic between Cry1Aa and Cry1C from Bacillus thuringiensis against Spodoptera exigua and Helicoverpa armigera. Lett Appl Microbiol 40:460-465

Yamamoto T, McLaughlin RE (1981) Isolation of a protein from the parasporal crystal of Bacillus thuringiensis var. Kurstaki toxic to the mosquito larva, Aedes taeniorhynchus. Biochem Biophys Res Commun 103:414-421

Zhang LL, Lin J, Lu OSL, Guan CY, Zhang QL, Guan Y, Zhang Y, Ji JT, Huang ZP, Guan X (2007) A novel Bacillus thuringiensis strain LLB6, isolated from bryophytes, and its new cry2Ac-type gene. Lett Appl Microbiol 44:301-307

Zhao JZ, Cao J, Li Y, Collins HL, Roush RT (2003) Earle, E.D., Shelton, A.M.: Transgenic plants expressing two Bacillus thuringiensis toxins delay insect resistance evolution. Nature Biotechnol 21:1493-1497

Zhao JZ, Cao J, Collins HL, Bates SL, Roush RT, Earle ED, Shelton AM (2005) Concurrent use of transgenic plants expressing a single and two Bacillus thuringiensis genes speeds insect adaptation to pyramided plants. Proc Natl Acad Sci USA 102:8426-8430 